\title{
Analysis of The Exemplary of Buya Ahmad Rasyid Sutan Mansur as Enrichment in History Learning at SMA Muhammadiyah 3 Surakarta
}

\author{
Ihsan $^{1}$, Sariyatun $^{2}$, Djono $^{2}$ \\ \{ihsan.1111@yahoo.com ${ }^{1}$, sari_fkip_uns@yahoo.co.id²,djono_sk@yahoo.com $\left.{ }^{3}\right\}$ \\ Master Program in History Education, Sebelas Maret University, Indonesia ${ }^{1}$, Sebelas Maret \\ University, Surakarta, Indonesia ${ }^{2,3}$
}

\begin{abstract}
The purpose of this study to analyze the exemplary of Buya Ahmad Rasyid Sutan Mansur as enrichment in history learning at SMA Muhammadiyah 3 Surakarta. This study uses a qualitative method with a Discourse Analysis approach. Data obtained through observation, interviews, documentation, with interactive analysis by Milles and Huberman. The results of this study indicate: (1.) Buya Ahmad Rasyid Sutan Mansur has 5 exemplary values including: Religious Values, Nationalism, Leadership and Struggle, Firmness of Establishment. (2.) Implementation of Historical Learning Based on the example of Buya Ahmad Rasyid Sutan Mansur at SMA Muhammadiyah 3 Surakarta has been running well and effectively, during Covid 19 through Google Classroom learning, teachers have referred to the 2013 Curriculum and compiled learning tools consisting of a syllabus, lesson plans. (3.) Teachers' Obstacles in Implementing History Learning at SMA Muhammadiyah 3 Surakarta, namely inadequate learning resources, too short learning time, and lack of student activity.
\end{abstract}

Keywords: Analysis, Exemplary, Buya A. R. Sutan Mansur, Enrichment, Learning History.

\section{Introduction}

Learning history is an effort that has been prepared by the teacher to be able to apply both knowledge, attitudes, and values related to a change and growth of ancient society to the Contemporary era in students should be applied in their lives. Historical learning not only provides historical knowledge related to facts, but historical learning can generate understanding and gain dignity from a historical event, historical knowledge is needed for all people from an early age so that they know and understand the meaning of a past event that can be used as a basis for acting and being able to see the reality at a later date, the need for history to be studied early on by each person, both formally and informally [1].

Historical learning has an important role in the process of actualizing the two elements of the learning process and education both (intellectual education and national moral education [2], so that educators must upgrade (improve) their professional competence, knowledge, beliefs, and teaching practices that are able to facilitate students to improve self-regulated-Thus, learning will increase [3]. In the process of actualization, historical awareness in learning can be found through an effort (a) to appreciate the importance of present and future history (b) be able to recognize himself and his nation (c) history in cultural fostering and nation (d) care for and preserve the nation's historical heritage [4], history learning plays a very important role in 
character building students The formation of character is expected so that students can someday become citizens who believe in God Almighty, have an attitude of nationalism and love for the country, apart from that, history learning in high school in the 2013 curriculum has been regulated and has a clear function and purpose, namely forming Indonesian human character to have a sense of nationality and love the country.

In shaping the character of students, history learning given at school is required to be able to make students as close to society as possible, because the history taught and the values contained in it are taken from a historical event that occurred in society. So history learning can be used as a means to maintain the identity and character of the nation. In fulfilling this goal, history learning based on local historical values can be used as an alternative solution. Therefore it is necessary to strengthen society in responding to global change through history and character-building requires a best practice of exemplary values contained in history learning, through historical learning exemplary values can be internalized to students [5].

In the context of history learning, the history learning design designed by educators must be able to facilitate students in making meaning from historical events [6], because history learning can develop various basic potentials of students in the values of wisdom, character and personality [7]. The ideal history learning facilitates students to achieve learning goals optimally [8]. Education must design innovative learning so that it can optimize students' abilities to be more competent [9]. innovative and creative history learning, in addition to increasing the professionalism of educators and developing student competencies related to historical material. That way, it is only natural in history learning to be introduced about exemplary values in local history to every student.

The development of technology and information influences all lines of life, although initially these developments were felt in institutions operating in the economic sector (companies). However, the Industrial Revolution 4.0 has had an impact not only on new approaches but on methodology and technology which in its development affects various fields of science, therefore it is time to be introduced to the community, especially academics [10].

The skills that students should have in the 21 st century As stated by Griffin, P \& Mc Gaw including, first, creativity, innovation, critical thinking, and the ability to solve problems, the ability to make decisions, and the ability to control cognitive aspects [11]. Second, namely, communication and cooperation skills. Third, namely, technology and information. Fourth, namely, being able to become good citizens of society, having personal and social responsibilities, and having awareness and having cultural competence. The existence of these skills is a requirement in learning history. Educators as agents of chang learning history learn a lot about past events, students will not be able to build their knowledge of historical events that are only told by educators e must be able to keep up with technological developments, as well as design creative and innovative learning [12], learning history learns a lot about past events, students will not be able to build their knowledge of historical events that are only told by educators [13], steps to build student abilities are by presenting historical events in the past so that students can appreciate and interpret them [14].

Related to the opinion expressed by Griffin, P \& Mc Gaw, above, historical learning about the analysis of Buya Ahmad Rasyid Sutan Mansur's example is needed to build various skills that are needed by students in the 21 st century, because in the history learning process related to the analysis of Buya Ahmad's example Rasyid Sutan Mansur can be a forum for developing creativity, innovation, critical thinking, the ability to solve problems, communication and collaboration skills, information literacy skills, information technology utilization skills and student communication skills, besides learning about the exemplary analysis of Buya Ahmad Rasyid Sutan Mansur, is very rich in exemplary values that can shape students into good citizens 
[15]. The exemplary values that Buya Ahmad Rasyid Sutan Mansur has, namely Religious, Nationalism, Leadership and Struggle and very high determination, these values are very important to be emulated and possessed by students today, and these values are very much needed in In the 21st century today, armed with religious values, nationalism values, leadership and struggle values as well as students' very high values of persistence, it will form a generation that has a strong character and becomes a strong personality. Students will become figures who work hard, never give up, and are full of independence in facing and answering the various challenges and obstacles that arise in the 21 st century, with these values students will dedicate all the abilities that exist in themselves for the progress of the nation and state in the current era of globalization.

The existence of Muhammadiyah schools will certainly make it easier to instill exemplary and Muhammadiyah values. SMA Muhammadiyah 3 Surakarta as one of the Muhammadiyah schools has of course implemented Islamic character values in the learning process through the school's vision and mission in realizing students with Islamic character, but there are still some students who have bad behavior, such as laziness in learning, students' lack of interest in learning, lack of discipline in carrying out prayers, lack of respect for speaking partners, and being impolite to friends and even teachers, and others. With the exemplary values of a figure who influences local or national history, especially in Muhammadiyah, it is expected that students can instill exemplary character in history learning in students as provisions in their daily lives, both at school and in the community [16]. Through exemplary and role models, he is able to form a good personality and is beneficial for his life, both from the school environment, family, and society [17].

\section{Research methods}

In this study, the researcher uses qualitative methods, qualitative research, which is a scientific approach that describes certain social situations that describe reality correctly, which is formed by words based on techniques for collecting analysis of relevant data obtained from natural situations [18]. With a Discourse Analysis approach using a Single Stylized Case Study Strategy. Data were collected through observation, in-depth interviews, and documentation study, with interactive analysis by Milles and Huberman [19].

\section{Results and Discussion}

\subsection{Identification of Buya Ahmad Rasyid Sutan Mansur's Exemplary Values As Enrichment In History Learning At SMA Muhammadiyah 3 Surakarta}

Buya Ahmad Rasyid Sutan Mansur's struggle in the trajectory of Indonesian history holds a lot of very relevant character values that can be imitated by the younger generation of students at this time. The identification of exemplary values owned by Buya Ahmad Rasyid Sutan Mansur includes Religious Values, Nationalism values, Leadership and Struggle, a very high stance, realizing each goal is full of challenges and obstacles, some even told him that Muhammadiyah people are Phanatic. To be a role model, of course, a character must have an advantage compared to others because an exemplary figure can increase the confidence of the community or students in the school environment to their example in carrying out the mandate [20]. 
As we can see that in the current implementation of National education, it tends to be practical-pragmatic and does not pay close attention to fundamental events such as the whole Indonesian people, therefore, it is necessary to express improvements in the quality of human personality and character. This is in line with the goals of education that are stated in Law no. 20 of 2003 . Which is currently being intensified by the government, especially through educational institutions, one of the values that are still relevant in addressing the problems of the Industrial era 4.0 is the Identification of Exemplary Values of Buya Ahmad Rasyid Sutan Mansur as enrichment in learning History at SMA Muhammadiyah 3 Surakarta.

Understanding of the Identification of Buya Ahmad Rasyid Sutan Mansur's Exemplary Values as Enrichment in History Learning at SMA Muhammadiyah 3 Surakarta, can be realized through the school's goals, vision, and mission. Which is the task of the school is to foster the vision and mission related to the exemplary values of Buya Ahmad Rasyid Sutan Mansur as enrichment in history learning implemented at SMA Muhammadiyah 3 Surakarta. As according to Agus Wibowo, revealed that the school has a strong obligation to regulate, become a driving force, and harmonize all existing educational resources [21]. The school principal is one of the aspects that can advance the school to realize the vision, mission, goals, and objectives of the school through activities that are carried out on purpose.

In history learning, values through figures are much more important, such as the identification of Buya Ahmad Rasyid Sutan Mansur's exemplary values as enrichment in history learning at SMA Muhammadiyah 3 Surakarta, which can provide a new perspective on historical values in the explanation of the character Buya Ahmad Rasyid Sutan Mansur. The study of figures as one of the intellectual historical heritage has an important role in the process of absorbing historical values, both from pioneering, exemplary, cultural, and social identities of historical figures. The importance of this historical value is that the character in the historical context finds several portions in historical learning. In history learning, the enrichment material that is studied has the value that the material studied by students in learning is no longer limited to historical events. where the 2013 Curriculum approach which is based on competence is a reference in learning history. This means that the thought of the 2013 Curriculum needs to be interpreted in the form of learning. Therefore, learning should be based on competency learning and not only learning the content of historical events where the content of historical events is a starting point in developing competence but considering that historical learning is a vehicle for the development of national life, therefore the content of historical events is very important to be expanded in historical material.

Identification of Buya Ahmad Rasyid Sutan Mansur's Exemplary Values as Enrichment in History Learning at SMA Muhammadiyah 3 Surakarta, is expected to be internalized as enrichment in students so that it can provide an understanding that eventually becomes a commonality and is expected to be applied to everyday life both in inside and outside the school environment, which grows through continuous history learning from an early age. Learning from history or studies related to the past should not be underestimated and considered unable to answer the problems that exist in the present era, in fact, the millennial generation (now) is experiencing moral degradation (decline), one of the causes is because it does not learn from history.The exemplary crisis has become a worrying epidemic in Indonesia, where the younger generation tends to actualize shows that are not worthy of being demanded, while demands are merely a spectacle. The hope is that history learning which has a value orientation can be used as a philosophical basis for the function of education [22]. Education as a cultural transformation means planting historical values from previous generations to the present generation. So that history finds an urgent position as one of the learning values in education, in fact, this is less attention and contrary to the conditions of historical learning, while historical values are needed 
in the inheritance of previous values in history learning, one of which is the Identification of the Exemplary Values of Buya Ahmad Rasyid Sutan Mansur as Enrichment in History Learning at SMA Muhammadiyah 3 Surakarta [23].

History is a continuous dialogue in a period divided into three perspectives, namely the past, present, and future. Buya Ahmad Rasyid Sutan Mansur is a figure from the past, but his role in the Indonesian nation can still be felt today. It can be seen from the movements of his steps, actions, attitudes, and struggles so that they can become a source of enthusiasm and role models for the younger generation, especially students. The study on the Identification of Buya Ahmad Rasyid Sutan Mansur's Exemplary Values as Enrichment in History Learning at SMA Muhammadiyah 3 Surakarta can be presented and inserted as material for enriching Indonesian History in class XI even semester which is contained in KD 3.6 Analyzing the Role of National and Regional Figures in Fighting for Indonesian Independence. Studies on the Identification of Buya Ahmad Rasyid Sutan Mansur's Exemplary Values as Enrichment in History Learning at SMA Muhammadiyah 3 Surakarta, from a historical perspective it is expected to foster Religious Values, Nationalism Values, Leadership and Struggle values as well as the value of Solid Establishment in students. So that in history subjects it becomes more meaningful by highlighting the character values contained in it, so that students can foster exemplary values such as Religious Values, Nationalism Values, Leadership and Struggle and very high values of Teguh Establishment, one of which is by exemplary method, namely having a role model or role model that can be used as an example by students.

\subsection{Implementation of History Learning Rests on the Example of Buya Ahmad Rasyid Sutan Mansur at SMA Muhammadiyah 3 Surakarta}

Learning implementation that implements historical learning based on the example of Buya Ahmad Rasyid Sutan Mansur is a follow-up to the planning process that has been compiled by the teacher in the form of a Learning Implementation Plan (RPP). The learning device must contain the values that will be implemented to students when the learning process takes place. The implementation of history learning based on the example of Buya Ahmad Rasyid Sutan Mansur at SMA Muhammadiyah 3 Surakarta is not only limited to planning but must be practiced in history learning, to implement these values can pass the method that will be used in the teaching and learning process. Implementation of Historical Learning Rests on the example of Buya Ahmad Rasyid Sutan Mansur has not been written into the RPP, but it has been applied in history learning very well because the stages that are no less important in learning are the implementation process and the implications of the planning. Efforts to transform the example of Buya Ahmad Rasyid Sutan Mansur, are implemented through history lessons carried out at schools. Implementation is a process related to implementation, ideas, concepts, policies, or innovation inefficient actions, which affects the form of transformation of knowledge, skills, and attitude values, while history is a branch of science that examines the origin and growth and role of society in the past. then based on certain methods and methodologies in which history means science that seeks to find, reveal, and understand the cultural values and meanings contained in past events [24].

The implementation of history learning based on the example of Buya Ahmad Rasyid Sutan Mansur at SMA Muhammadiyah 3 Surakarta which was carried out by the history subject teacher at SMA Muhammadiyah 3 Surakarta in Class XI referred to KD. 3.6 Analyzing the Role of National and Regional Figures in Fighting for Indonesian Independence. Which learning planning is a form of a process in deciding the results of thinking rationally (makes sense) regarding specific learning targets and objectives, which refers to changes in behavior patterns and a series of activities that must be carried out as a solution in achieving these goals using 
all existing learning capabilities and resources [25]. The results of this process are structured documents that can be used as a reference and guidelines for the implementation of learning activities in the future, in carrying out learning planning, one must look at opinions that can lead to a goal to be achieved. In carrying out better lesson planning, the process of implementing historical learning based on the example of Buya Ahmad Rasyid Sutan Mansur at SMA Muhammadiyah 3 Surakarta which was carried out during the Covid-19 Pandemic through Google Classroom could run well too, systematically and directed, in line with the opinion that was held stated by Muhammad Qasim Maskiah in his writing "Planning for Teaching in Learning Activities" in the Islamic Discourse Journal (2016) states that teaching planning is a stage in the learning process to try as much as possible so that teaching is successful. One aspect that can bring success is that teachers always make lesson plans beforehand, teaching planning is a program of how to teach what is stated in the 2013 Curriculum, in learning activities alluding to three domains, namely, attitudes, knowledge, and skills through results learning to be achieved to produce productive, creative, innovative, and affective students through strengthening attitudes, skills and knowledge that have been integrated [26].

In planning the history teacher has prepared a learning tool in the form of a Learning Implementation Plan (RPP). And closing activities. Basic Competencies that have been planned in the RPP by Ibuk Indah Rahmawati Akbar, S. Pd, as a history teacher, carry out learning at two meetings where the time allocation is $2 \times 45$ minutes or 90 minutes, Ibuk Indah Rahmawati makes the best use of her teaching time and hours through Google Classroom, so this is where the important role of the teacher in time management and managing learning [27].

Given the importance of learning history in an educational context, it must contribute to the formation of character and self-identity. What is the orientation in the development of history subjects in the world, for the realization of individual nations who have high integrity and are aware of the development of the nation [28], inline with this history teacher Ibuk Indah Rahmawati Akbar, S. Pd., Stated that learning history is the same as building us. the future, because by studying history we are expected not to repeat mistakes that occurred in the past, history itself has a lot of value that can be reaped and can be applied in life as long as we study it well. Implementation of History Learning Rests on the example of Buya Ahmad Rasyid Sutan Mansur at SMA Muhammadiyah 3 Surakarta is not only neatly stored in books but with historical learning, exemplary values and thoughts can be used and transferred to students [29].

The implementation of learning is the teacher's obligation in cultivating all the abilities that exist in students, the main course in the history learning process needs to change student behavior based on the goals formulated by the teacher at the beginning of the process of history learning activities taking place, the teacher as a catalyst means that the teacher plays a role in helping students to get the strengths, talents (talents), and the advantages that exist in them, the teacher acts as a guide, helps direct and develop aspects of the personality, character, and emotions, intellectual (scientific) aspects of students, so that students can understand that the correct learning process is a process that is continuous [30].

Because it requires an innovation that can boost historical achievement and student interest in learning history. This opportunity for the author is very relevant when implementing historical learning based on the example of Buya Ahmad Rasyid Sutan Mansur at SMA Muhammadiyah 3 Surakarta as a solution to this. Seeing that the function of learning history is very important for the nation's future generations, it requires learning innovations that are following current conditions [31]. The demand for the need for historical learning is of course the main thing in implementing historical learning based on the example of Buya Ahmad Rasyid Sutan Mansur at SMA Muhammadiyah 3 Surakarta, which must offer a value offer to historical 
events or figures, to increase students' imagination about past events. So that learning history, in general, must contribute values to student life. In this application, it is hoped that the aim of implementing History Learning is based on the example of Buya Ahmad Rasyid Sutan Mansur at SMA Muhammadiyah 3 Surakarta is in line with the vision and mission of the school which was launched, in the sense that it can bridge the vision and mission in SMA Muhammadiyah 3 Surakarta.

The history teacher explained that history learning at SMA Muhammadiyah 3 Surakarta had already referred to the applicable syllabus and curriculum, in its implementation it went well and effectively even though during the Covid-19 Pandemic it was carried out via Google Classroom with $2 \times 45$ minutes or 90 minutes. In the implementation of learning, it was first introduced by introducing National and Regional Figures who were influential in history and students were asked to choose one of the characters and then memorize the motto of the character by conducting discussions, presentations, and the students were asked to explore on their own and the teacher asked questions and affirmation so that in the history learning process there are students who are enthusiastic but there are those who are less enthusiastic about using strategies and methods, the Discovery Learning learning model and discussions by holding quizzes and post-tests.

History learning, which is carried out by history teachers at Muhammadiyah 3 Surakarta Senior High School is the right means of implementing History Learning based on the example of Buya Ahmad Rasyid Sutan Mansur at SMA Muhammadiyah 3 Surakarta because students have been faced with formal (valid) situations and places in carrying out Learning Activities. Whereas historical material is a fundamental educational material for the process of reforming and creating the civilization of the Indonesian nation in the future, and solidarity (togetherness) to become the nation's glue in facing the threat of disintegration of the Western nation with moral teachings and wisdom that are useful in overcoming crises in developing the responsible attitude and maintain balance and environmental sustainability [32].

In this study, the authors used the Enrichment Triad Model Theory initiated by Joseph .S Renzulli. According to Renzulli's opinion, this enrichment model has 2 directions, namely First, it provides opportunities for students to foster their interest, Second, helps students identify pragmatically, to solve problems that match their interests, and be able to produce appropriate products. In the Enrichment Triad, the activity model felt by students in its application is divided into three stages, including 1.) Type I General Explorator (General Exploration). 2) Type II Activities (Group Training Activities) Group Training. 3) Type III Individual And Small Group Investigation Of Real (Real Individual and Small Group Investigation). 


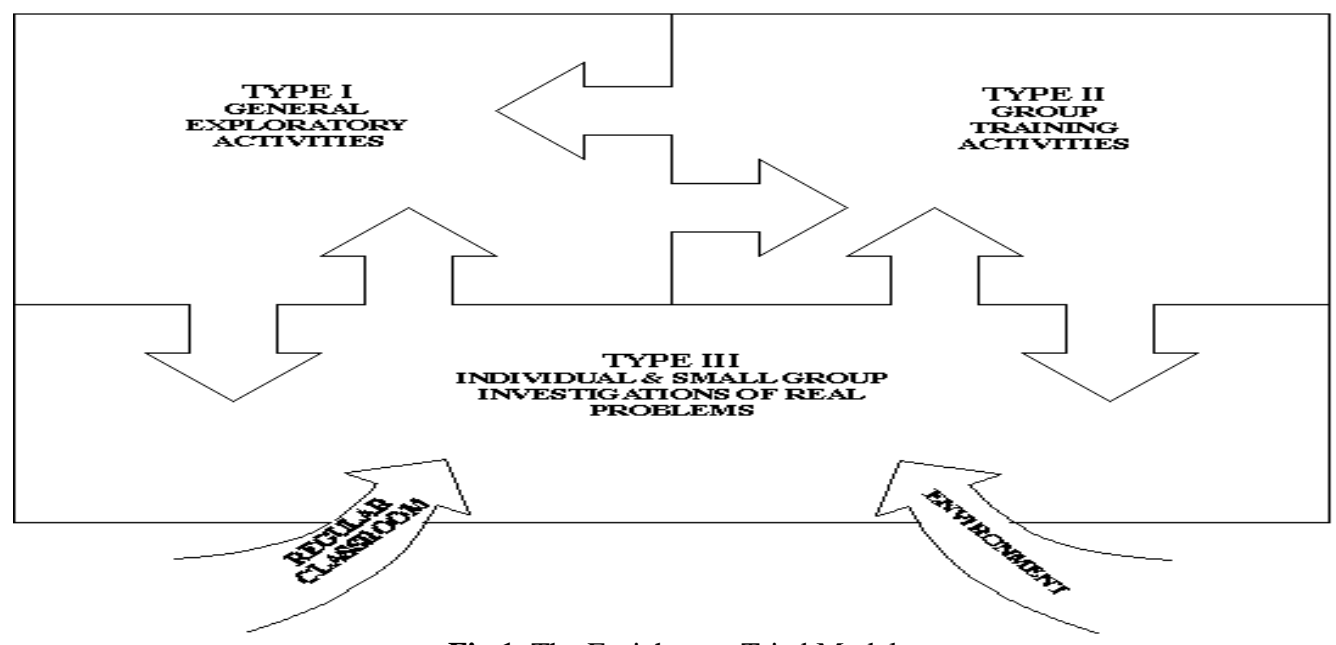

Fig 1. The Enrichment Triad Model

The Triad Enrichment Model is divided into three types of enrichment which are initially implemented in an enrichment program designed for academically gifted and talented students. However, the need for learning encourages educators to make Enrichment so that they can bridge the birth of new talents [33].

Stage I. is designed to enrich students' intellectuals, in this case, the teacher implements historical learning based on the example of Buya Ahmad Rasyid Sutan Mansur at SMA Muhammadiyah 3 Surakarta in the History Learning Implementation Plan, which is easier to apply it to history subjects, because students are equipped with various historical figures, both figures local and national figures and local culture, as well as role models that can attract students' interest in learning. So that students can more easily understand these exemplary values. The implementation of historical learning based on the example of Buya Ahmad Rasyid Sutan Mansur at SMA Muhammadiyah 3 Surakarta was carried out as an effort to prepare against the exemplary crisis that hit the Indonesian nation, especially students at SMA Muhammadiyah 3 Surakarta. The implementation of history learning based on the example of Buya Ahmad Rasyid Sutan Mansur at SMA Muhammadiyah 3 Surakarta can be done through history learning, namely, dislip through Basic Competencies 3.6 Analyzing the Role of National and Regional Figures in Fighting for Indonesian Independence. In Type III, the hope is that students can be more motivated to develop experiences independently.

Stage II. Includes materials and methods designed to promote thinking and feeling processes. The method is interpreted as a method used to achieve predetermined learning objectives without a good and suitable method, so what is desired in learning will not be achieved. In this case, the history teacher uses the discussion method in learning it must be by the circumstances and situations of the students, to create a conducive and good atmosphere, in line with this history teacher Ibuk Indah Rahmawat Akbar, S.Pd, stated that supporting facilities in learning is like Study books for teachers and students, image projectors (LCD) and other supporting facilities are good. The school tries to provide the best for students at SMA Muhammadiyah 3 Surakarta, because with good facilities it can guarantee good quality education for teachers and students in teaching and learning [34]. Furthermore, the teacher in Implementing History Learning Based on the example of Buya Ahmad Rasyid Sutan Mansur at 
SMA Muhammadiyah 3 Surakarta with the Discovery Learning model on the problems that occur in the current era. In the sense that the teacher makes students the figure of Buya Ahmad Rasyid Sutan Mansur in the current era. The teacher provides contemporary problems to make students have the ability to develop creativity, innovation, critical thinking, the ability to solve problems, the ability to communicate and work together, as well as the ability to utilize technology and information as well as students' communication skills. So that it can bridge the interests in Stage III

Stage III. Involving students and focusing students on learning activities and developing experiences independently means that activities that students must do in obtaining information and new competencies must be under the desired constructivist goals (generative, namely an act of fostering something meaning in what has been learned). Then able to adapt their teaching activities to the styles and characteristics of student learning), in this case, students are given the breadth of doing assignments independently in exerting each of their respective abilities which can later be used in the learning process in taking roles as role models for students

In this section the teacher motivates the study of Buya Ahmad Rasyid Sutan Mansur who can inspire life in Implementing History Learning Based on the example of Buya Ahmad Rasyid Sutan Mansur at SMA Muhammadiyah 3 Surakarta, the teacher gives similar tasks related to heroes or warrior figures in the history of the Indonesian nation, especially within Muhammadiyah which has inspired to this day.

Theoretically, evaluation is a systemic and systematic effort in collecting, looking for explanations, and processing data and the objective information is to conclude the value, importance of a program and the results of these conclusions can be used to make a decision, plan, or improve a program. In the effort of modification, innovation (diversion), and improvisation (provision) of effective historical subject matter, therefore, an appropriate evaluation model is needed on the effectiveness of historical subject matter. Before explaining further about the assessment we first want to review three terms that are often confused in everyday life, namely teaching, evaluation, assessment, and testing. Assessment is a process of gathering information to determine the extent to which the learning objectives that have been applied are to be achieved. This information can be in the form of words from teachers, parents, quality of books, assessment results, and student attitudes. Evaluation in the form of tests, questionnaires interviews, and observations. Assessment, which includes all the methods used regarding the collection of information regarding the knowledge, abilities, understanding, attitudes of students which can be carried out through tests, self-assessment both formally and informally, while testing is one of the procedures that can be applied in assessing student performance. Tests can be objective, and subjective. The test is a way of measuring a person's ability, both in terms of knowledge and performance in a predetermined domain [35]. Evaluation or assessment of learnin in implementing historical learning based on the example of Buya Ahmad Rasyid Sutan Mansur at SMA Muhammadiyah 3 Surakarta is the final component of history learning. Assessment is a form that is very decisive in evaluating teaching and learning outcomes in schools [36]

In the Learning Implementation Plan (RPP), Ibuk Indah Rahmawati Akbar, S.Pd, plans, and evaluation of history learning using several assessment models. These learning models are designed in the Learning Implementation Plan (RPP), the evaluation of learning outcomes will run well and be carried out if in practice adhere to three principles, namely the overall principle, continuity, and the principle of objectivity, this is based on the aspects used as an assessment of learning outcomes which is guided by the Cognitive, Affective and Psychomotor aspects, which in the Cognitive (knowledge) aspect the history teacher at SMA Muhammadiyah 3 Surakarta 
uses written test assessments and assignments, while in the skills aspect uses the analysis summarized by the students. These assessments have been planned and can be applied in the evaluation of the learning history of National and Regional Figures in Fighting for Indonesian Independence and the Role of National and Regional Figures in Fighting for Indonesian Independence. Depends on student needs.

\subsection{Teacher Constraints In The Implementation Of History Learning At SMA Muhammadiyah 3 Surakarta}

In implementing learning, it is closely related to a conducive environment where students can learn actively, and the formation of aspects of knowledge, attitudes, and skills of students, as well as adjustments to activity plans and class management. In the teaching and learning process, it must be environmentally oriented and adhere to the principles of personality and educational outcomes that are useful and can be used by the community. As Muhammad Yusri, Muhammad argues that learning and teaching activities can be said to be successful in the process, if students have to play an active role both physically and mentally then that is where the teaching and learning process can be said to be successful in learning [37]. Implementing History Learning Based on the example of Buya Ahmad Rasyid Sutan Mansur at SMA Muhammadiyah 3 Surakarta is not a process that can be carried out briefly. In that sense, after students know about the exemplary values of Buya Ahmad Rasyid Sutan Mansur. There needs to be coherence and continuity from various parties so that students try to instill these exemplary values. In essence, students at SMA Muhammadiyah 3 Surakarta have shown good character, the obstacle faced by a teacher is that students have not fully tried to instill character values in themselves. Even though students already know the exemplary values, but besides that, the teacher has tried to continue to instill and provide examples for their students, so that they can do actions that reflect exemplary values.

At the planning level in the preparation of the Learning Implementation Plan (RPP), there are no obstacles, in the preparation of learning objectives, there are no obstacles at all. However, it appears at the level of activity, at the level of student activity is quite good and so far effective in learning, but some students in learning history through Google Classroom at SMA Muhammadiyah 3 Surakarta, while history teachers teach history learning there are students who are enthusiastic, but there are students who less enthusiastic in learning, therefore, the activeness of students in the history learning process also influences the implementation of historical learning based on the example of Buya Ahmad Rasyid Sutan Mansur at SMA Muhammadiyah 3 Surakarta to the students themselves, another obstacle in implementing historical learning is based on exemplary Buya Ahmad Rasyid Sutan Mansur at SMA Muhammadiyah 3 Surakarta, which is in the time allocation used by history teachers that in providing history learning material to students the time is too short so that it is constrained when the learning is carried out, and the discu method the group used in learning activities is not going well. Because in group discussions it took a long time, so group discussion activities were continued in learning at the next meeting, because the time allocation for history lessons became a serious obstacle in the history learning process at school, in line with what Leo Agung said. S. in his writing entitled "Development of a Character Education Based High School History Learning Model in Solo Raya" (2012) in the Journal of Education and Culture, states that the obstacles to learning history include limited teaching time, lack of sourcebooks as a student guide or other references. which supports learning, as well as the absence of a laboratory or IPS / History Lap as well as the existence of a description from the Public regarding the lessons in the UAN and those not in the UAN, the lack of enthusiasm for reading the students and the facilities and infrastructure provided [38]. Apart from some of the existing obstacles, another 
obstacle is that there are problems with the learning resource books, where the sourcebooks are inadequate in the learning process, so that there is a lack of material to be completed in learning, but besides that, it is supported by other sources such as worksheets, and supported by interactive multimedia sources and the Internet.

\section{Conclusion}

A figure and scholar who deserves to be emulated must have morality, intelligence, and ability to organize, in the implementation of Historical Learning Based on the example of Buya Ahmad Rasyid Sutan Mansur at SMA Muhammadiyah 3 Surakarta has been running quite well and effectively, in the history learning process during the Covid 19 Pandemic through Google Classroom, Constraints in Implementing History Learning at SMA Muhammadiyah 3 Surakarta, namely inadequate learning resources, insufficient learning time, while the subject matter is large, due to the different character of students.

Acknowledgments. I would like to thank SMA Muhammadiyah 3 Surakarta, Principal, History Teacher, to the Editor of the International Conference Proceedings (EAI-CCER SERIES) and also to the reviewer team, I hope my writing can be taken into consideration for acceptance.

\section{References}

[1] Amin. S. 2010. Pewarisan Nilai Sejarah Lokal Melalui Pembelajaran Sejarah Jalur Formal dan Informal Pada Siswa SMA di Kudus Kulon."Tesis".Surakarta. Pendidikan Sejarah UNS; 2 p.

[2] Isjoni. 2007. Saatnya Pendidikan Kita Bangkit. Referensi.

[3] Umamah, Nurul. 2017. Pembelajaran Sejarah Kesiapannya Menghadapi Tantangan Zaman. Prosiding Kapita Selekta (Pendidikan) Sejarah Indonesia. 14-18 Desember 1917.,

[4] Aman. 2014. Aktualisasi Nilai-Nilai Kesadaran Sejarah Dan Nasionalisme Dalam Pembelajaran Sejarah Di SMA. Jurnal Pendidikan Karakter Tahun IV, No. 1 Februari, No. 1 (2014), 23-34.

[5] Tsabit Azinar Ahmad. 2014. Kendala Guru Dalam Internalisasi Nilai Karakter Pada pembelajaran Sejarah. Jurusan Ilmu Kependidikan. Vol. VII,.

[6] Umamah. 2014. Perencanaan Pembelajaran. Jember: Universitas Jember.

[7] Hamid Hasan Said. 1998. Kebijakan dan Pelaksanaan Sejarah Di Lingkungan Depdikbud "dalarn Simposium Pengajaran Sejarah (Kumpulan Makalah). Jakarta: Depdikbud;

[8] Na'im M, \&, Sumardi. 2017. The Development Of Digital Module Through Exe Application Based To Improve Learners Attraction And Learning Outcomes Of Indonesia History. Int J Soc Sci Humanit Invent. 4 (7):.:3582.

[9] Umamah. 2015. Teachers, Innovative, Instructional Design and a Good Character In Information Era. Proceeding Int Semin Educ Nation Character Buiding. 231-5.

[10] Benesovaa, A. \& Tupaa, J. 2017. Education And Qualitative Of People In Industry. 27 th Int Conf Flex Autom Intell Manuf. 2195.

[11] Griffin, P \& Mc Gaw B. 2012. Assessment And Teaching Of 21st Century Skills. New York: Springer.

[12] Umamah. 2015. Teachers, Inovative, Instructional Design and a Good Character In Information Era. Proceeding of Internasional Seminar Education For Nation Character Buiding. 231-35.

[13] Umamah. 2014. Perencanaan Pembelajaran. Jember: Universitas Jember;

[14] Puji \& Umamah. 2018. Edmodo Multi-Media: Supporting Technology For Media Learning at Higher Education. Int J English Lit Soc Sci. 3 (1)((LJELS). 
[15] Griffin, P \& Mc Gaw B. 2012. Assessment And Teaching Of 21st Century Skills. New York: Springer.

[16] Arifin Z. 2017. Implementasi Pendidikan Karakter Islami Pada Kegiatan Ekstrakurikuler "Hizbul Wathan" (Studi Empirik di SMA Muhammadiyah 3 Surakarta). Universitas Muhammadiyah Surakarta.

[17] Firdaus AH, Purnomo A, Ahmad TA. 2018. Kesadaran Sejarah Siswa Terhadap Ketokohan dan Keteladanan Sunan Kudus Di MA Qudsiyyah Kudus Tahun Pelajaran 2017/2018. Indones J Hist Educ. 6(2):150-61.

[18] Moleong, J. Lexy. 2014. Metode Penelitian Kualitatif. Edisi Revi. Bandung: PT. Remaja Rosda karya. $4 \mathrm{p}$.

[19] Mattew B. Miles, Dan, and Amichael Huberman. 2007. Analisis Data Kualitatif Buku Sumber Tentang Metode-Metode Baru., ed. by Terjemahan Tjetjep Rohendi Rohisi. Jakarta: Universitas Indonesia.

[20] Madiyono. 2020. Wawancara Pribadi Dengan Kepala Sekolah SMA Muhammadiyah 3 Surakarta. Kota Surakarta.

[21] Wibowo, Agus. 2013. Pendidikan Karakter di Perguruan Tinggi. Yogyakarta: Pustaka Pelajar; 119 p.

[22] Tilaar, H.A.R. 2002. Pendidikan, Kebudayaan, dan Masyarakat Madani Indonesia: Strategi Reformasi Pendidikan Nasional. In Ketiga.

[23] Kurniawan, H. 2013. Penanaman Karakter Melalui Pembelajaran Sejarah Dengan Paradigma Konstruktivistik Dalam Kurikulum 2013. Socia. 10 (1), Pp

[24] Abdurrahman, D. 1999. Metode Penelitian Sejarah. Jakarta: Logos Wacana Ilmu; 3 p.

[25] Sukino, Pujo Dkk. 2017. Pembelajaran Sejarah di Kelas XI Madrasah Aliyah Assalam Pontianak. $J$ Pendidik Sos. Vol. 4, No.

[26] Maskiah, Muhammad Qasim. 2016. Perencanaan Pengajaran Dalam Kegiatan Pembelajaran. $J$ Diskurs Islam. Vol. 04 No.

[27] Akbar, Indah Rahmawati. 2020. Wawancara Pribadi Dengan Guru Sejarah SMA Muhammadiyah 3 Surakarta.

[28] Kobrin, David, Ed Abbott, John Elinwood and DH. 1993. Learning History by Doing History. Educational Leadership. 50:39-41.

[29] Akbar, Indah Rahmawati. 2020. Wawancara Pribadi Dengan Guru Sejarah SMA Muhammadiyah 3 Surakarta. Jl. Kolonel Sutarto No. 62, Jebres, Kec. Jebres, Kota Surakarta.;

[30] Utomo, CB. 2012. Model Kepemimpinan dan Suasana Akademik Dalam Pembelajaran Sejarah SMA di Kota Semarang. Pramita Hist Stud J. 22, No.1:98.

[31] Leo Agung Sutimin, Sariyatun, And, Abidin NF. 2018. The Development Of Deconstructive Learning History Model to Promote The Higher Order Thinking Skill Of University Students. New Educ Rev. 1 (1), 19-.

[32] Akbar, Indah Rahmawati. 2020. Wawancara Pribadi Dengan Guru Sejarah SMA Muhammadiyah 3 Surakarta.

[33] Semiawan C. 2004. Perspektif Anak Berbakat. Jakarta: Grasindo; 83 p.

[34] Nuriyah N. 2014. Evaluasi pembelajaran: Sebuah Kajian Teori. J Edueksos.

[35] Firdaus, P. dan Ahmad. 2018. Kesadaran Sejarah Siswa Terhadap Ketokohan dan Keteladanan Sunan Kudus Di MA Qudsiyyah Kudus Tahun Pelajaran 2017/2018. Indones J Hist Educ. Vol 6 No $2: 151$.

[36] Yusri, Muhammad. 2011. Teknik Guru Dalam Mengatasi Hambatan Proses Pembelajaran. Jakarta: PT. Remaja Rosdakarya; 13 p.

[37] Leo Agung S. 2012. Pengembangan Model Pembelajaran Sejarah SMA Berbasis Pendidikan Karakter di Solo Raya. Pendidik dan Kebud. Vol. 18, N.

[38] Nurul Umamah. 2017. Pembelajaran Sejarah Kesiapannya Menghadapi Tantangan Zaman. Pros Kapita Sel Sej Indonesia. 14-18 Desember 1917. 